\section{'Plum Crimson' Fresh-Market Plum Tomato Hybrid and its Parents, NC EBR-7 and NC EBR-8}

\author{
R.G. Gardner \\ North Carolina State University, Raleigh, NC 27695-7609
}

Additional index words. Lycopersicon esculentum, Alternaria solani, og gene, I-3 gene, fusarium wilt, early blight

'Plum Crimson' is a fresh-market plum (Roma type) tomato (Lycopersicon esculentum Mill.) with crimson fruit color, resistance ( $I-3$ gene) to race 3 of fusarium wilt (Fusarium oxysporum f. sp. lycopersici (Sacc.) Snyder $\&$ Hansen) and moderate resistance to early blight (Alternaria solani (Ellis and Martin) Jones and Grout).

\section{Origin}

'Plum Crimson' (NC EBR-7 × NC EBR-8) is the product of a breeding effort to improve disease resistance, fruit quality, and fruit size in an early blight resistant fresh-market plum tomato similar to the hybrid 'Plum Dandy' (Gardner, 2000). Development of NC EBR-7, the female parent of 'Plum Crimson', involved a cross of the male sterile cherry tomato line $\mathrm{NC}$ 2C $m s-10$, aa (Gardner, 2000) to NC EBR-5, the female parent of 'Plum Dandy' (Fig. 1). This cross was followed by backcrossing to NC 630-1(95)-Bk-Bk, a line derived from selfing 'Plum Dandy'. Selfing and selection followed each backcross to retain the $m s-10$ gene for male sterility linked to the green stem $(a a)$ seedling marker trait. The male parent of 'Plum Crimson' (NC EBR-8) resulted from a self of the cross of the large, round-fruited tomato line Fla. $7547 \times$ NC EBR-6, the male parent of 'Plum Dandy'. Fla. 7547 (Scott, 1995) was the source of the $I-3$ gene incorporated into NC EBR-8. NC EBR-7 and -8 were both selected for the recessive $o g^{c}$ gene, which confers crimson fruit color and increased lycopene content. The $\operatorname{og}^{c}$ gene is present in both Fla. 7547 and NC EBR-6.

\section{Description}

'Plum Crimson'(NC 98128) has been tested in replicated trials at the Mountain Horticultural Crops Research Station, Fletcher, N.C., in early and late season trials each summer since 1998. 'Plum Crimson' was equivalent to 'Plum Dandy' in total and marketable yields over 10 trials and exceeded 'Plum Dandy' in

Received for publication 14 Mar. 2005. Accepted for publication 23 Nov. 2005. The use of trade names in this publication does not imply endorsement by the North Carolina Agricultural Research Service (NCARS) of the products names, nor criticism of similar ones not mentioned. This research was funded by the NCARS and the North Carolina Tomato Growers Association. average fruit weight (Table 1). 'Plum Crimson' exceeded 'Peto 882' in total and marketable yields and in fruit size.

Fruit of 'Plum Crimson' are typical fresh-market plum shape, elongate [length to diameter $(\mathrm{L} / \mathrm{D})$ ratio of $1.7: 1]$ with a slight taper from the shoulder to the blossom end. The blossom ends are smooth and free of nipples. Fruit have two or three locules and are well-filled with thick fruit walls. Fruit pedicels are jointed, and immature fruit have a glossy, uniform green color ( $u$ gene). Ripe fruit are moderately firm (subjective ratings) and develop bright red interior flesh and gel color as a result of the crimson gene. Based on many subjective ratings, flavor of 'Plum Crimson' was rated comparable to that of 'Plum Dandy'. Fruit are highly resistant to

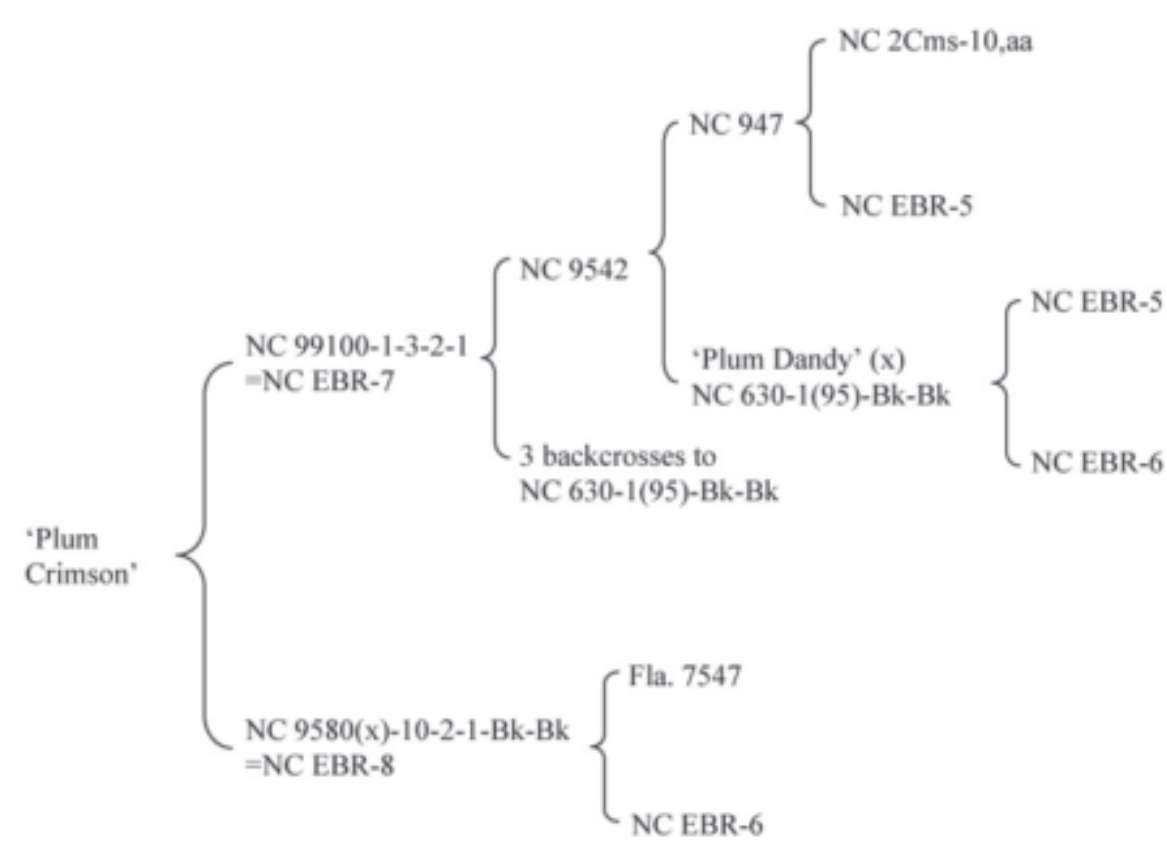

Fig. 1. Pedigrees of 'Plum Crimson' $F_{1}$ hybrid tomato and its parent lines, NC EBR-7 and NC EBR-8.

Table 1. Comparison of 'Plum Crimson' ${ }^{\mathrm{Z}}$ with standard plum tomato cultivars in staked, vine-ripe harvest trials at Fletcher, N.C.

\begin{tabular}{|c|c|c|c|c|}
\hline \multirow[b]{3}{*}{ Cultivar } & \multicolumn{3}{|c|}{ Yield $\left(\mathrm{t} \cdot \mathrm{ha}^{-1}\right)$} & \multirow{3}{*}{$\begin{array}{l}\text { Fruit } \\
\text { wt (g) }\end{array}$} \\
\hline & \multirow{2}{*}{$\begin{array}{c}\text { Early season } \\
\text { nongraded }\end{array}$} & \multicolumn{2}{|c|}{ Total season } & \\
\hline & & $\overline{\text { Nongraded }}$ & $\overline{\text { Marketable yield }}$ & \\
\hline Plum Crimson & 21 & 106 & 99 & 125 \\
\hline Plum Dandy & 24 & 105 & 88 & 101 \\
\hline Peto 882 & 21 & 90 & 66 & 105 \\
\hline $\mathrm{LSD}_{0,01}$ & NS & 14 & 15 & 8 \\
\hline
\end{tabular}

${ }^{2}$ Based on 10 replicated trials conducted over a 5-year period (1998-2002).

${ }^{\mathrm{y}}$ First 2 weeks of harvest. 
EBR-7 line heterozygous for the linked genes $m s-10$ and $a a$ produces $25 \%$ of the seedling population with green stems, $90 \%$ of which are male sterile at flowering. Stigmas on flowers of the male sterile plants are generally exserted sufficiently that pollen of the male parent can be applied without emasculating the flowers.

NCEBR-7 has a vigorous determinate plant $(s p)$. Leaves are long with long, narrow leaflets, which exhibit some twisting and distorted shape. Foliage cover is moderately heavy and resembles that of 'Plum Dandy' and other lines derived from the early blight resistant USDA line 71B-2. Fruit have two or three locules and are elongate $(\mathrm{L} / \mathrm{D}$ ratio of $2: 1)$ with jointless pedicels $(j 2)$. Fruit average $140 \mathrm{~g}$ and have a fairly cylindrical shape with a taper at the blossom and stem end. Blossom ends of the fruit are smooth and free of nipples. Fruit are resistant to cracking and weather check and develop deep red interior color as a result of the crimson $\left(\operatorname{og}^{c}\right)$ gene. Color images of $\mathrm{NC}$ EBR-7 and NC EBR-8 can be viewed at the website www.ces.ncsu.edu/fletcher/programs/ tomato/. Immature fruit are glossy, uniform green $(u)$. NC EBR-7 has the $I$ gene for resistance to fusarium wilt race 1 and the Ve gene for resistance to verticillium wilt (Verticillium dahliae Kleb). It is moderately resistant to early blight. NC EBR-7 is segregating for the $m s-10$, a a linkage combination.

NCEBR-8 has a vigorous determinate plant $(s p)$ with dark green foliage. Fruit pedicels are jointed. Fruit are ovate (L/D ratio of 1.4:1) and are highly resistant to fruit cracking and weather check. Fruit have two or three locules and develop a deep red interior color as a result of the crimson gene. Immature fruit are glossy, uniform green $(u)$. In two replicated trials at Fletcher in 2001, NC EBR-8 did not differ from 'Plum Crimson' in total or marketable yields. However, the average fruit size of NC EBR-8 (108 g) was less than that of 'Plum Crimson' (128 g). NC EBR-8 has the $I, I-2$, and $I-3$ genes for resistance to races 1,2 , and 3 of fusarium wilt and the $\mathrm{Ve}$ gene for resistance to verticillium wilt.

\section{Use}

'Plum Crimson' provides growers in North Carolina and other regions with similar growing conditions a high yielding, disease resistant fresh-market plum tomato cultivar with improved color and larger fruit size than 'Plum Dandy'. It is well adapted to both vineripe and mature-green harvest. NC EBR-7 and NC EBR-8 provide tomato breeders with unique combinations of disease resistance, fruit quality, and male sterility and should be useful in breeding or directly as parents in other $\mathrm{F}_{1}$ hybrids.

\section{Availability}

'Plum Crimson' was released on an exclusive basis for seed production and sales to Harris Moran Seed Co. and is currently available. Small samples of 'Plum Crimson' and its parent lines, NC EBR-7 and NCEBR-8, are available from R.G Gardner, MHCREC, 455 Research Drive, Fletcher, NC 28732. Recipients of NC EBR-7 and NC EBR-8 will be required to sign a seed transfer agreement before receiving seed.

\section{Literature Cited}

Gardner, R.G. 2000. 'Plum Dandy', a hybrid tomato and its parents, NC EBR-5 and NC EBR-6. HortScience 35:962-963.

Gardner, R.G. 2000. A male-sterile cherry tomato breeding line, $\mathrm{NC} 2 \mathrm{C} m s-10, a a$. HortScience 35:964-965.

Scott, J.W. and J.P. Jones. 1995. Fla. 7547 and Fla. 7481 tomato breeding lines resistant to Fusarium oxysporum f. sp. lycopersici races 1, 2, and 3. HortScience 30:645-646. 